\title{
Investigation Of Optimize Wax Pattern In The Investment Casting By Using The Different Form Of Waxes
}

\author{
Er. Charanjeet singh Sandhu ${ }^{1}$, Er. Ajay Sharma ${ }^{2}$ \\ ${ }^{1}$ (Deptt Of Mechanical Engineering, Shaheed Udham Singh College Of Engineering And Technology, \\ Punjab Technical University Punjab, India) \\ ${ }^{2}$ (Deptt Of Mechanical Engineering, Swami Devi Dyal Institute of Engineering \\ Kurukshetra University, Haryana, India)
}

\begin{abstract}
Investment casting process used for precision component manufacture calls for accurate method design. It gives good surface finish, high dimensional accuracy, and complex shape. But due to some defects produced by the wax patterns result in the poor quality of the final casting product. The some common defects are like Shrinkage, inadequate surface finish, improper dimensional accuracy in the wax patterns. So there is need to remove these defects. The wax pattern handled during the melting, injecting will reflect the quality of wax pattern produced for the investment. Hence in the present work an attempt is made to produce the good quality wax pattern by using the different form of wax like Paraffin wax, Bee wax, Montan wax, Carnauba wax, China wax. We will vary the proportion of these waxes and make the different samples. In each sample we will find out the volumetric shrinkage, linear shrinkage, cracks formation etc.
\end{abstract}

Keyword: - investment casting, air forced oven, wax pattern

\section{Introduction}

Now a day's investment casting interest is increasing day by day due to its ability of producing near net shaped result of excellent surface finish, dimensional accuracy, and complex shapes. Approximate $40 \%$ of worldwide investment casting production. The steps which are used in the investment casting are a) production of master pattern b) mould making c) production of wax pattern d) assemble wax pattern e) investment $f$ ) dewaxing g) burnout and preheating h) pouring I) removal. The main part of the investment casting is the wax pattern. Because the quality of the final cast product is depend upon the wax pattern. It is produced by pouring the molten wax into the permanent mould of desire shape and size. A wax pattern should have some properties for making the pattern like lowest thermal expansion, low melting point, low shrinkage, good surface finish, eco friendly etc. in this work we are going to make a such combination of the waxes which will give all the properties which are desire to make the pattern.

\subsection{Introduction about the Waxes:-}

1.1.1 Bee wax: - Beeswax is a natural wax produced in the bee hive of honey bees of the genus Apis. It is mainly esters of fatty acids and various long chain alcohols. Beeswax has a high melting point range, of 62 to 64 ${ }^{\circ} \mathrm{C}\left(144\right.$ to $\left.147^{\circ} \mathrm{F}\right)$. If beeswax is heated above $85^{\circ} \mathrm{C}\left(185^{\circ} \mathrm{F}\right)$ discoloration occurs. The flash point of beeswax is $204.4{ }^{\circ} \mathrm{C}\left(399.9^{\circ} \mathrm{F}\right){ }^{[6]}$ Density at $15{ }^{\circ} \mathrm{C}$ is 958 to $970 \mathrm{~kg} / \mathrm{m}^{3}$. Its main components are palmitate, palmitoleate, hydroxypalmitate and oleate esters of long chain alcohols (C30-32) (about 70 to $80 \%$ of the total weight). One of the properties of bees wax is that, it gives better surface finish.

1.1.2 Carnauba wax : - it is also called Brazil wax and palm wax, is a wax of the leaves of the palm Copernicia prunifera, a plant native to and grown only in the northeastern Brazilian states of Piauí, Ceará, and Norte. It is known as "queen of waxes" and usually comes in the form of hard yellow-brown flakes. It is obtained from the leaves of the carnauba palm by collecting them, beating them to loosen the wax, then refining and bleaching the wax. Carnauba consists mostly of aliphatic esters (40 wt \%), diesters of 4-hydroxycinnamic acid (21.0 wt \%), $\omega$ hydroxycarboxylic acids (13.0 wt \%), and fatty acid alcohols (12 wt \%). The compounds are predominantly derived from acids and alcohols in the C26-C30 range. Distinctive for carnauba wax is the high content of diesters as well as methoxycinnamic acid. Melting point: $82-86{ }^{\circ} \mathrm{C}\left(180-187^{\circ} \mathrm{F}\right)$, among the highest of natural waxes, higher than beeswax, $62-64 \mathrm{C}$. Relative density is about 0.97 . It is among the hardest of natural waxes.

1.1.3 Montan wax: - Montan wax, also known as lignite wax or OP wax is a hard wax obtained by solvent extraction of certain types of lignite or brown coal. Commercially viable deposits exist in only a few locations, including Amsdorf, Germany, and in the Ione Basin near Ione, California. Its color ranges from dark brown to light yellow when crude, or white when refined. Its composition is non-glyceride long-chain (C24-C30) 

carboxylic acid esters (62-68 weight \%), free long-chain organic acids (22-26\%), long-chain alcohols, ketones, and hydrocarbons $(7-15 \%)$, and resins; it is in effect a fossilized plant wax. Its melting range is $82-95{ }^{\circ} \mathrm{C}$.

1.1.4 Paraffin wax: - In chemistry, paraffin is a term that can be used synonymously with "alkane", indicating hydrocarbons with the general formula $\mathrm{C}_{n} \mathrm{H}_{2 n+2}$. Paraffin wax is found in the solid state at room temperature and begins to enter the liquid phase past approximately $37^{\circ} \mathrm{C}\left(99^{\circ} \mathrm{F}\right)$. One of the properties of paraffin wax is that, it gives better surface finish.

1.1.5 China wax: - is a white to yellowish-white, gelatinous, crystalline water-insoluble substance obtained from the wax secreted by certain insects.

It resembles spermaceti but is harder, more friable, and with a higher melting point. It is deposited on the branches of certain trees by the scale insect Ceroplastes ceriferus, common in China and India, or a related scale insect, Ericerus pela, of China and Japan. The insects and their secretions are harvested and boiled with water to extract the raw wax. The insect bodies, which settle to the bottom, are used as food for swine.

Table 1, Properties of wax

\begin{tabular}{|l|l|l|l|l|l|}
\hline Sr no. & Name of the wax & Density & $\begin{array}{l}\text { Melting } \\
\text { point }\end{array}$ & $\begin{array}{l}\text { Volumetric } \\
\text { shrinkage }\end{array}$ & Flash point \\
\hline 1 & Paraffin wax & $0.78 \mathrm{gm} / \mathrm{cc}$ & $52-74^{\circ} \mathrm{C}$ & 6.20 & $275^{\circ} \mathrm{C}$ \\
\hline 2 & Bee wax & $\begin{array}{l}958 \text { to } 970 \\
\mathrm{~kg} / \mathrm{m}^{3} .\end{array}$ & $\begin{array}{l}62 \text { to } 64^{\circ} \mathrm{C} \\
(144 \text { to } \\
\left.147^{\circ} \mathrm{F}\right) .\end{array}$ & $\begin{array}{l}204.4{ }^{\circ} \mathrm{C} \\
\left(399.9{ }^{\circ} \mathrm{F}\right) .\end{array}$ \\
\hline 3 & Carnauba wax & $0.97 \mathrm{gm} / \mathrm{cc}$ & $\begin{array}{l}82-86 \quad{ }^{\circ} \mathrm{C} \\
(180- \\
\left.187^{\circ} \mathrm{F}\right)\end{array}$ & 5.45 & $300{ }^{\circ} \mathrm{C}$ \\
\hline 4 & China wax & $0.82 \mathrm{gm} / \mathrm{cc}$ & $62-75^{\circ} \mathrm{C}$ & 6.28 & $318^{\circ} \mathrm{F}$ \\
\hline 5 & Montan wax & $1.02 \mathrm{gm} / \mathrm{cc}$ & $82-95^{\circ} \mathrm{C}$. & 2.45 & $300.26 \mathrm{C}$ \\
\hline
\end{tabular}

\section{Literature Review}

[1] Timothy M.Wolff found that the way pattern wax is handled during the melting and injection stage of prepattern production will directly reflect the quality of the wax pattern produced in the wax room. Proper handling method can eliminate a multitude of the wax pattern defects for the investment casting foundries. It is important to recognize that all the material used to produce the casting are part of the system and must work together to make a quality cast. Therefore, the final casting can only be as good as wax pattern produced.

[2] Bonilla found that the injection parameters play an important role in the accuracy of the wax patterns. These parameters include: the injection flow rate; the injection cycle time; the injection temperature; the injection pressure; and the die temperature.

[3] J.-C. Gebelin, M.R. Jolly, A. M. Cendrowicz, J. Cirre and S. Blackburn used the three different experiments. The first was to characterize the flow of the wax during the filling and the capacity of the models developed to describe it accurately, in the liquid state. The second experiment was to test the capacity of the models to predict the apparition of filling defects. The third was to compare the predictions in liquid and paste or semi-solid state. A good agreement between experiments and simulations has been found, showing that the models are able to represent the behavior of the wax used.

[4] Qingbin Liu, Ming C. Leu used the ice pattern by rapid freezing prototype. Ice patterns generated by rapid freeze prototyping or a molding process can be used to make ceramic investment molds for metal castings. Due to the use of ice, the ceramic slurries must be poured around the pattern and cured at sub-freezing temperatures. Success of this process depends greatly on the mold strength after the gelatin of the slurries.

[5] Gebelin and Jolly explained that the accuracy of the wax patterns used has a direct effect on the accuracy of the final cast part. They also concluded that, it is usual for the investment caster to use precision-machined full metal dies for producing wax patterns when large numbers of highly accurate components are required.

[6] Harvey Fielder, Investment casting waxes are injected or extruded into tooling cavities to form disposable patterns and related assemblies for subsequent processing in the precision investment casting (PIC) process. The flow characteristics, or rheology, of these waxy materials play a crucial part in determining dimensional and surface quality of the injected part. 
[7] Vojtech Kosour used the wax model created by using the silicon mold in a vacuum chamber, rapid prototype method used for manufacturing small series of prototype products from many different material like resins, plastics fibers etc. The RP method will be practically shown for a particular model, which earlier used to be made by injection of wax into aluminum mould.

[8] Dr. K. D. Desai Mr. Raghav Ramdas a new innovation in lost wax investment casting process. The new innovative technology gives enhanced quality of gold and platinum jewelry at reduced cost. The innovation potentially reduces the process timing and at the same time improves the quality. The concept is based on the quick and efficient removal of carbonized wax and gases generated during casting from the investment mold.

From the above literature review it has been found that lot of work is carried out on the investment casting some of them used rapid freezing prototype for the ice pattern some of them used Silicon, Plastic, Paraffin wax, Bee wax etc mostly paraffin wax is used for making the wax pattern due to its property of produce the better finish but it does not gives the dimensional accuracy. At some foundry it uses a Carnauba wax because it gives the better dimensional accuracy but poor surface finish similarly with the Bee wax, Montan wax etc. ice pattern gives the better accuracy at the corner points but temperature maintenance is very difficult, plastic and silicon produces the cracks in the pattern.

All of these the wax is good for making the pattern because it is easy to shape, cheap and can give the high degree of accuracy. Now we are going to use the different form of waxes to produce good wax pattern

\section{Experimental Procedure}

The all experiment will be done in the following step

1. Sample making using different form of wax

2. Die design

3. Pattern making by using different sample

4. Find out the best solution

\subsection{Sample Making by Using Different Type of Wax}

The following samples has been created by using the bee wax, Montan wax, paraffin wax, china wax, carnauba wax which are shown in the table

Table 2 Sample Making

\begin{tabular}{|c|c|c|c|c|c|}
\hline Sample no. & $\begin{array}{c}\text { Paraffin wax } \\
(\%)\end{array}$ & Bee wax $(\%)$ & $\begin{array}{c}\text { Montan wax } \\
(\%)\end{array}$ & $\begin{array}{c}\text { Carnauba } \\
\text { wax }(\%)\end{array}$ & $\begin{array}{c}\text { China wax } \\
(\%)\end{array}$ \\
\hline 1 & 50 & 30 & 0 & 20 & 0 \\
\hline 2 & 50 & 30 & 20 & 0 & 0 \\
\hline 3 & 50 & 30 & 10 & 10 & 0 \\
\hline 4 & 60 & 20 & 10 & 10 & 0 \\
\hline 5 & 70 & 10 & 10 & 10 & 0 \\
\hline 6 & 80 & 5 & 5 & 5 & 5 \\
\hline 7 & 100 & 0 & 0 & 0 & 0 \\
\hline 8 & 50 & 20 & 10 & 10 & 10 \\
\hline 9 & 40 & 20 & 20 & 10 & 10 \\
\hline 10 & 20 & 20 & 20 & 20 & 20 \\
\hline
\end{tabular}

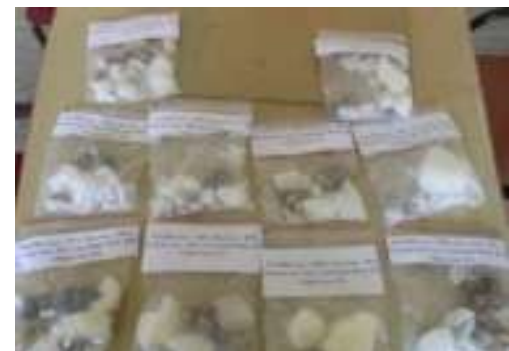

Figure 1, number of sample prepared

3.2 Die design and Pattern Making: - Firstly die is prepared the material of the die is mild steel and the shape and size of the material is shown in the fig 


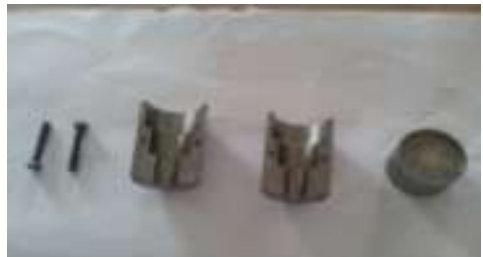

FIGURE 2, DIE DESIGN

After making the die, wax pattern is prepared by mixing together different form of waxes according to weight as shown in the table. Die is heated up to $48{ }^{\circ} \mathrm{C}$ in the forced air oven and the wax is heated at the temperature is $68^{\circ} \mathrm{C}$ in the forced air oven. After injecting the wax it is cooled down to the room temperature then the pattern is removed from the die.

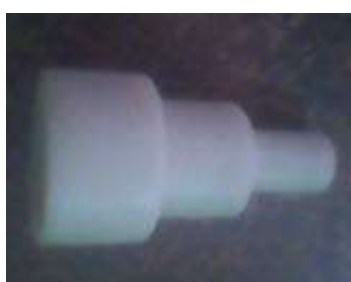

\section{FIGURE 3, PATTERN MAKING}

There are two main shrinkage allowances to be considered: the die-to-wax shrinkage and the casting solidification shrinkage. Then the following defects are consider after making the pattern

1. Linear shrinkage

2. Volumetric shrinkage

We can directly calculate the linear shrinkage by taking the difference between the standard dimension of the die and the dimension that we get from the pattern.

Volumetric shrinkage can be find out as follow

1. Firstly Make the die leak proof

2. After that fill the water in the die cavity and measure the volume of the water that will give the volume of the die

3. Fill the water in the measuring flask and take the initial reading then place the wax pattern in the measuring flask now the volume of the water rises that is final volume

4. Take the difference of the final volume and the initial volume it will give the volume of the pattern

5. Now the volumetric shrinkage is find out as

(Volume of the die - volume other pattern/ volume of the die)*100

\section{Result And Discursion}

From the experiment conduct we find out the linear shrinkage of the different samples as well as the volumetric shrinkage. After calculating the linear shrinkage we found the following result as shown in the table below

Table 3, Linear Shrinkage

\begin{tabular}{|c|c|c|c|c|c|c|}
\hline $\begin{array}{c}\text { Sample } \\
\text { no. }\end{array}$ & $\begin{array}{c}\text { Paraffin } \\
\text { wax } \\
(\%)\end{array}$ & $\begin{array}{c}\text { Bee } \\
\text { wax (\%) }\end{array}$ & $\begin{array}{c}\text { Montan wax } \\
(\%)\end{array}$ & $\begin{array}{c}\text { Carnauba } \\
\text { wax (\%) }\end{array}$ & $\begin{array}{c}\text { China } \\
\text { wax (\%) }\end{array}$ & $\begin{array}{c}\text { Linear } \\
\text { shrinkage in } \\
\%\end{array}$ \\
\hline 1 & 50 & 30 & 0 & 20 & 0 & 1.78 \\
\hline 2 & 50 & 30 & 20 & 0 & 0 & 1.20 \\
\hline 3 & 50 & 30 & 10 & 10 & 0 & 1.18 \\
\hline 4 & 60 & 20 & 10 & 10 & 0 & 1.07 \\
\hline 5 & 70 & 10 & 10 & 10 & 0 & 1.20 \\
\hline 6 & 80 & 5 & 5 & 5 & 5 & 1.15 \\
\hline 7 & 100 & 0 & 0 & 0 & 0 & 1.07 \\
\hline 8 & 50 & 20 & 10 & 10 & 10 & 0.98 \\
\hline 9 & 40 & 20 & 20 & 10 & 10 & 1.14 \\
\hline 10 & 20 & 20 & 20 & 20 & 20 & 3.27 \\
\hline
\end{tabular}




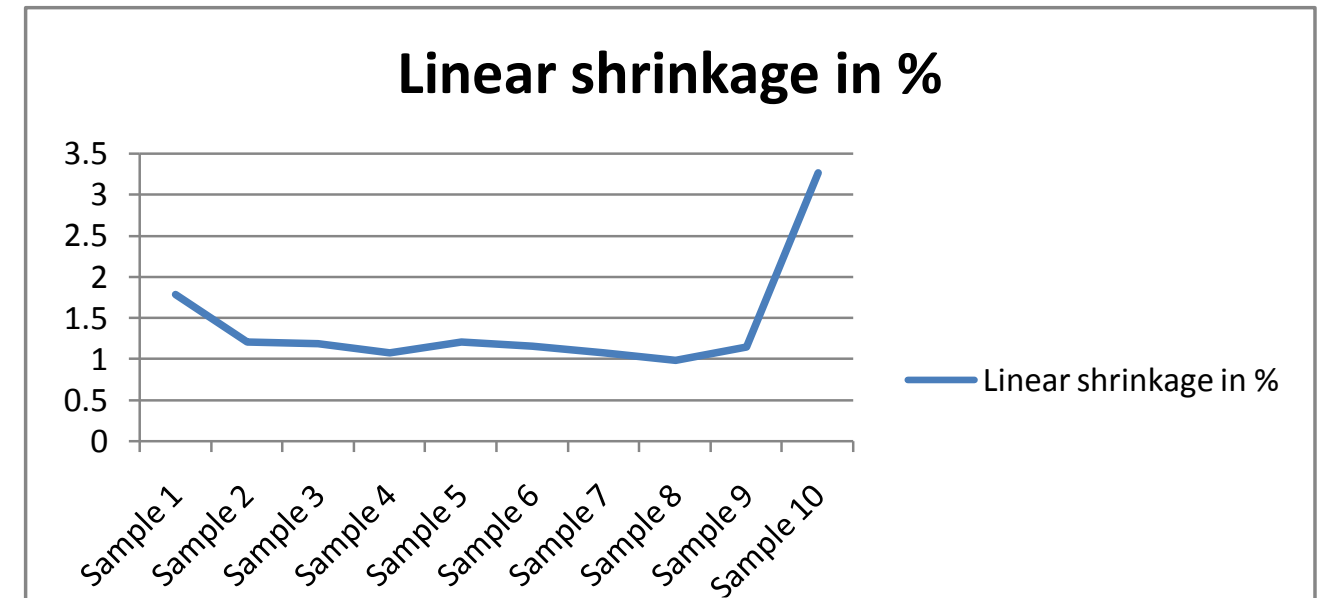

Figure 4 Linear Shrinkage Graph

After calculating the volumetric shrinkage we find out the following result as shown in the table below.

Table 4, volumetric shrinkage

\begin{tabular}{|c|c|c|c|c|c|c|}
\hline $\begin{array}{c}\text { Sample } \\
\text { no. }\end{array}$ & $\begin{array}{c}\text { Paraffin } \\
\text { wax (\%) }\end{array}$ & $\begin{array}{c}\text { Bee wax } \\
(\%)\end{array}$ & $\begin{array}{c}\text { Montan } \\
\text { wax }(\%)\end{array}$ & $\begin{array}{c}\text { Carnauba } \\
\text { wax }(\%)\end{array}$ & $\begin{array}{c}\text { China } \\
\text { wax } \\
(\%)\end{array}$ & $\begin{array}{c}\text { Volumetric } \\
\text { shrinkage } \\
\text { in } \%\end{array}$ \\
\hline 1 & 50 & 30 & 0 & 20 & 0 & 4.57 \\
\hline 2 & 50 & 30 & 20 & 0 & 0 & 5.23 \\
\hline 3 & 50 & 30 & 10 & 10 & 0 & 6.60 \\
\hline 4 & 60 & 20 & 10 & 10 & 0 & 3.98 \\
\hline 5 & 70 & 10 & 10 & 10 & 0 & 3.22 \\
\hline 6 & 80 & 5 & 5 & 5 & 5 & 2.53 \\
\hline 7 & 100 & 0 & 0 & 0 & 0 & 3.12 \\
\hline 8 & 50 & 20 & 10 & 10 & 10 & 4.51 \\
\hline 9 & 40 & 20 & 20 & 10 & 10 & 4.73 \\
\hline 10 & 20 & 20 & 20 & 20 & 20 & 6.82 \\
\hline
\end{tabular}

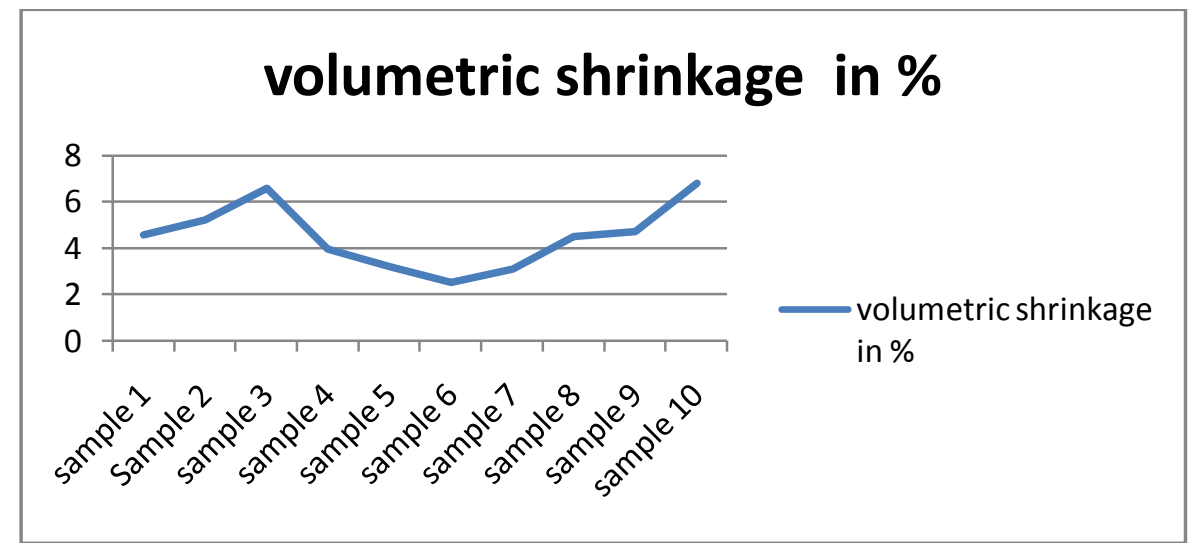

Figure 5 Volumetric Shrinkage Graph

All experiment is done to find out the best possible result and we find the value of volumetric shrinkage and linear shrinkage. We plot the graph and find out the optimum value where we get the least value of the linear shrinkage as well as volumetric shrinkage. 


\section{Conclusion}

On the basis of experimental observations made on WAX PATTERN components following conclusions can be drawn

1. Shrinkage affected by the type of wax used and was sensitive to the site at which dimensional measurements were performed.

2. There is a significance effect of wax temperature, initial die temperature and ambient temperature on final wax pattern

3. The sample with proportion of $80 \%$ paraffin wax, $5 \%$ bee wax, $5 \%$ Montan wax , 5\% carnauba wax, $5 \%$ china wax will gives the better result of linear shrinkage as well as volumetric shrinkage

4. Types of wax also effect the defect produces in the wax pattern

\section{References}

[1]. Timothy M. Wolff, Margueso\& Co., inc. Muskegon, Michigan, investment casting waxes influence which eliminate wax pattern defects

[2]. W. Bonilla, S. H. Masood and P. Iovenitti, "An investigation of wax patterns for accuracy improvement in investment casting parts”, Bulletin of Industrial Research Institute of Swineburne, Melbourne, Australia, vol. 18, 2001, pp 348 - 356.

[3]. J.C. Gebelin and M.R. Jolly, "Modeling of the investment casting process", Journal of Material Processing Technology, vol. 135, 2003, pp $291-300$.

[4]. Tascroglu and N. Akar, "A novel alternative to the additives in investment casting pattern wax compositions", Materials and Design, vol. 24, 2003, pp $693-698$.

[5]. Freund, Mihály; Mózes, Gyula; Jakab, E. (trans) (1982). Paraffin products: properties, technologies, applications. Amsterdam, Netherlands: Elsevier. p. 121. ISBN 0-444-99712-1.

[6]. Williams R.B. Review of world Investment Casting Markets, $12^{\text {th }}$ World Conference on Investment Casting, Oct. 2008.

[7]. Wei Zhang, Ming C. Leu, Investment Casting with Ice Patterns Made by Rapid Freeze PrototypingQingbin Liu, Ming C. Leu, Study of Ceramic Slurries for Investment Casting with Ice Patterns. 